\author{
Artur Sajnóg \\ University of Lodz, Faculty of Economics and Sociology, \\ Department of Finance and International Investments \\ e-mail: artur.sajnog@uni.lodz.pl \\ ORCID: 0000-0001-9475-8848
}

\title{
EFFECTS OF COMPREHENSIVE \\ INCOME REPORTING ON JUDGMENTS \\ OF NON-PROFESSIONAL INVESTORS
}

\section{RAPORTOWANIE WYNIKU CALKOWITEGO W OPINII NIEPROFESJONALNYCH INWESTORÓW}

\author{
DOI: $10.15611 / \mathrm{pn} .2020 .3 .06$ \\ JEL Classification: G21, M41, M48
}

\begin{abstract}
Summary: This study examines the usefulness of comprehensive income as important information in the financial statements for the purpose of making investment decisions by Polish non-professional investors. The discussed research problem was realised in two parts. The first part depicts mainly theoretical reflections on the concept of comprehensive income and its strengths and weaknesses for investors. The second part outlines the survey results on the usefulness of comprehensive income in the opinions of individual investors which show that respondents assessed comprehensive income (including its components) as important for making investment decisions. At the same time, users of financial statements were quite unanimous that the implementation of comprehensive income to the financial reporting system increased the transparency of information and allowed for more accurate financial analyses of joint stock companies. In many cases, comprehensive income was considered to be a better measure of economic efficiency and market value than 'traditional' net income.
\end{abstract}

Keywords: comprehensive income, income reporting, net income, investors, investment decisions.

Streszczenie: W artykule przeanalizowano przydatność wyniku całkowitego jako ważnej informacji w sprawozdaniach finansowych dla podejmowania decyzji inwestycyjnych przez nieprofesjonalnych inwestorów w Polsce. Omawiany problem badawczy został zrealizowany w dwóch częściach. Pierwsza część przedstawia główne teoretyczne refleksje na temat koncepcji wyniku całkowitego oraz potencjalnej jego użyteczności informacyjnej dla inwestorów. Druga część obejmuje zaś rezultaty badań ankietowych na temat przydatności wyniku całkowitego w opiniach inwestorów indywidualnych. Wyniki badań pokazują, że respondenci ocenili wynik całkowity (wraz z jego komponentami) jako ważny przy podejmowaniu decyzji inwestycyjnych. Stwierdzili ponadto, że implementacja wyniku całkowitego do systemu sprawozdawczości finansowej zwiększyła przejrzystość informacji i przysłużyła 
się pełniejszemu zrozumieniu i poprawnej analizie finansowej spółek akcyjnych. W wielu wypadkach wynik całkowity był uważany za lepszą miarę efektywności ekonomicznej i wartości rynkowej niż tradycyjny wynik netto.

Słowa kluczowe: wynik całkowity, raportowanie wyniku, wynik netto, inwestorzy, decyzje inwestycyjne.

\section{Introduction}

The aim of financial reporting is to communicate to capital market participants all the information, including internal, which can be useful in predicting future financial performance, particularly in estimating a company's value. Such intent has guided the implementation of the comprehensive income category to the financial reporting system of a company, forcing the need to analyse its gains and losses, which are a result of all of its actions, regardless of where in financial reporting they are positioned. Information about the firm's comprehensive income should therefore help managers, investors, analysts and others to evaluate the company's actions as well as recognise the economic efficiency and market value and its future performance. However, the practical application of comprehensive income in making investment decisions creates a range of difficulties and proves to be highly controversial.

In international literature, one can find a number of arguments to justify both the greater and lesser role of comprehensive income as a more important financial measure for making investment decisions (Nelson and Tayler, 2007; Kang and Zhao, 2010). In contrast to this research, others - sometimes even supporters of the implementation of the comprehensive income category to financial reporting - do not give a definite answer in this regard. Moreover, their later findings demonstrate the advantages of net income in relation to the weaknesses of the investment decisions which are made on the basis of comprehensive income (Ketz, 1999; Eaton, Easterday, and Rhodes, 2013).

The essential aim of this paper is to identify the preferences of individual investors as regards the use of information in the comprehensive income statement for the purpose of making investment decisions. In order to accomplish that aim, a general research hypothesis was formulated which assumes that comprehensive income is considered to be a better financial measure than net income, in particular that it is more useful for the purposes of company valuation, more related to the market price of shares, and has a higher predictive value.

The direct premise of the study was the lack of research in literature, not on the motives of implementation of comprehensive income to the company's financial reporting system, but rather on the usefulness of this category for investors in Poland. Although one can find papers dealing with the topic of comprehensive income in Polish literature, these studies mainly concern issues from the field of accounting, 
especially the form and structure of the comprehensive income statement (Szychta and de la Rosa, 2012; Bek-Gaik, 2013; Gad, 2017). Thus, identifying the profile and preferences of Polish individual investors in the use of information retrieved from financial statements for the purpose of making investment decisions creates relatively new challenges for scientific research and is not present in literature.

The discussed research problem was addressed in two parts. The first part depicts mainly theoretical reflections on the concept of comprehensive income and its strengths and weaknesses for investors. The second part outlines survey results on the usefulness of comprehensive income in the opinion of 100 individual investors.

\section{Usefulness of comprehensive income for investors}

In the theory and practice of a company's strategic financial management, which is oriented to increase the shareholder value, the essential attention is concentrated on determinants of changes in the value and structure of equity. In this context an important role is played by comprehensive income (all-inclusive income), which is generally understood to represent shareholder's wealth. According to the comprehensive income concept, profit is a positive change in the value of a company's net assets (equity) between the end and the beginning of an accounting period. A positive change of equity is understood as equivalent to 'wealth' for shareholders and profit expresses the utility of using equity in a given period and shows the overall increase (or decrease) in shareholder's wealth (Epstein, Nach, and Bragg, 2010). Therefore, comprehensive income reporting requires showing most of the items making up both the company's value and shareholder value (Ramond, Casta, and Lin, 2007).

Net profit is connected with the concept of operating profit, namely the measure of the efficiency of the company and its management. It is generated by recurrent operations of the entity. Moreover, comprehensive income (CI) consists of net income (NI) and the results of other transactions with non-owners - other comprehensive income (OCI) - see Figure 1.

Reporting CI, together with components of OCI, is due to the necessity of fully presenting, properly reflecting and understanding the implemented various strategies of equity management to increase the market value of a firm as well as the future benefits for investors. Not only does the scope of CI, reported in the proper statement, have a broader problem area in comparison to NI but it also contains a number of significant effects of the value creation process and factors that drive the company's future performance (Kanagaretnam, Mathieu, and Shehata, 2009).

However, the practical application of CI for the purpose of making investment decisions creates a range of difficulties and proves to be highly controversial. The form and presentation of the structure of companies' CI are not homogenous (Sajnóg, 2017). The scope of the provided data, as a result of the various and imprecise terms used for the description of OCI, may adversely affect the clarity and transparency of such a statement, causing limitations or lack of information suitability for investors. Henry 


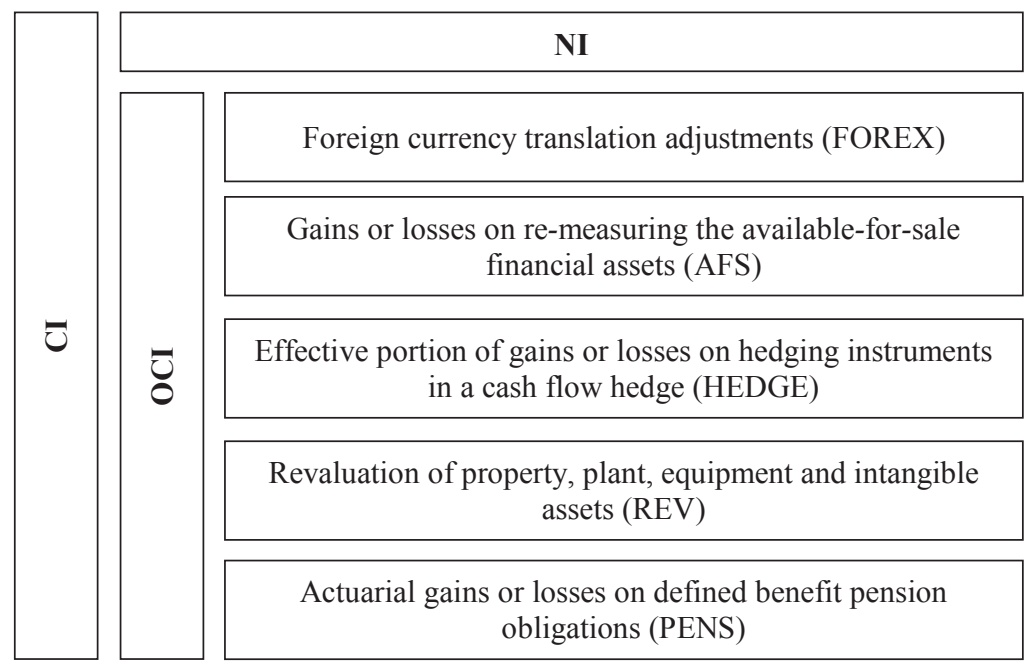

Fig. 1. Overview of CI and its components under IFRS

Source: own study on the basis of (Pronobis and Zülch, 2011).

(2011) finds that components of OCI are more volatile than NI and this high volatility can lower share prices and increase the cost of capital. Moreover, the degree of persistence of OCI has significant implications for the company value. As a result, OCI items may mislead the investors in measuring performance given by their volatility.

The evidence in prior research indicates that investors may not rationally decompose income into accrual and cash components when making investment decisions. Therefore, then they may weigh the aggregated information (e.g. CI) more heavily in their decision-making (Maines and McDaniel, 2000). Libby, Bloomfield, and Nelson (2002) documented that investors can stray from rational decision models by increasing the costs of disentangling income components. The evidence of other studies showed that investors fail to fully understand difficult categories, e.g. components of OCI (Hodder, Hopkins, and Wood, 2008).

In general, it is important for investors to know which earnings, even those that are still not realised, exist in the financial statement (Hoogervorst, 2012). Kang and Zhao (2010) documented that the elements that make up CI show a more significant value relevance for financial investors. Ketz (1999) neither confirmed nor rejected the hypothesis that $\mathrm{CI}$ is more relevant to users of financial statements than NI and that it is reasonable to include the statement on comprehensive income into the set of obligatory financial statements. Eaton, Easterday, and Rhodes (2013) generally confirmed this opinion too. Cahan, Courtenay, Gronnewoller, and Upton (2000) argued that the value relevance of CI items did not change after IFRS implementation, although they concluded that comprehensive income reporting matters to investors, yet the usefulness of OCI components is highly questionable. 
Some researchers pointed out that analysts use information contained in comprehensive income in updating their forecasts. Additionally, $\mathrm{CI}$ is useful in predicting changes in NI of the next period (Choi and Zang, 2006). Other authors found a higher association of CI with share prices and stock returns than NI (Kubota, Suda, and Takehara, 2009; Kanagaretnam et al., 2009). In contrast to this research, (Barton, Hansen, and Pownall, 2010) evidenced the greater association of NI with market value in comparison to CI. They definitely concluded that CI has the lowest ability to predict operating cash flows of the eight performance measures considered.

In light of these controversies, it is worth emphasising that comprehensive income reporting, including all components of OCI, reduces the cognitive costs of data acquisition and processing, thus rendering this information more assessable for making decision (Nelson and Tayler, 2007). Prior to the adoption of IFRS, listed companies were required to present some components of CI in the statement of changes in equity, but the new statement of comprehensive income, which concluded these categories, can be more useful for investors. This group has special abilities to assess company performance using comprehensive income in the presence of earnings management. This definitely means that investors are able to correctly assess firm performances only when OCI is presented directly in a comprehensive income statement. Presenting various assets or liability remeasurements allows investors to define and make their own judgments in the investment process.

\section{Comprehensive income importance - survey results}

The research used a questionnaire survey, based on the prepared version of the questionnaire for respondents. The surveys were conducted on a sample of 100 individual investors ${ }^{1}$. The sampling involves non-random selection based on the criterion of availability. The CAWI method was used for the selection of the sample ${ }^{2}$.

The results of the survey show that individual investors were mainly aged 36-45, and $51 \%$ were men and $49 \%$ women. More than three-quarters of the respondents had over five years of investment experience and, at least at the declarative level, extensive investment knowledge and experience in implementing IFRS into the accounting system.

Individual investors generally think that IFRS, unlike the Polish Accounting Act, gives extensive freedom to corporate managements to choose from a wide range of possible reporting treatments, especially in the form and structure of the comprehensive income statement. This opinion was shared by $40 \%$ of all respondents, but 34 of them had no opinion on this subject. The respondents confirmed that the

${ }^{1}$ Defined as people not investing on someone else's behalf, they manage their own money.

2 The surveys were carried out by Grupa Best Sp. z o.o. in Katowice between 16.09.2019 and 30.11.2019, as part of the funds awarded by the National Science Center (project number: 2018/28/T/ NZ9/00074). 
implementation of $\mathrm{CI}$ to the financial reporting system in Poland increased the transparency of information (48 affirmative answers) and its usefulness (72). Additionally, according to $77 \%$ investors, the CI reporting allowed for more accurate financial analyses of joint stock companies (see Table 1).

Table 1. The assessment of the CI implementation to the financial reporting system

\begin{tabular}{|l|c|c|c|}
\hline \multicolumn{1}{|c|}{ Questions } & Yes & No & $\begin{array}{c}\text { No } \\
\text { opinion }\end{array}$ \\
\hline $\begin{array}{l}\text { IFRS gives extensive freedom to corporate managements to choose } \\
\text { from a wide range of possible reporting treatments }\end{array}$ & 40 & 26 & 34 \\
\hline The CI implementation increased the transparency of information & 52 & 27 & 21 \\
\hline The CI implementation increased the usefulness of information & 72 & 15 & 13 \\
\hline $\begin{array}{l}\text { The CI reporting allowed for more accurate financial analyses of stock } \\
\text { companies }\end{array}$ & 77 & 15 & 8 \\
\hline
\end{tabular}

Source: own study.

The analysis of the data presented in Figure 2 leads to the conclusion that individual investors assess the comprehensive income category as important for making investment decisions. CI was also important in investment decisions for nearly $70 \%$ of individual investors (see Figure 2). It is significant that $83 \%$ of them had over five years of investment experience.

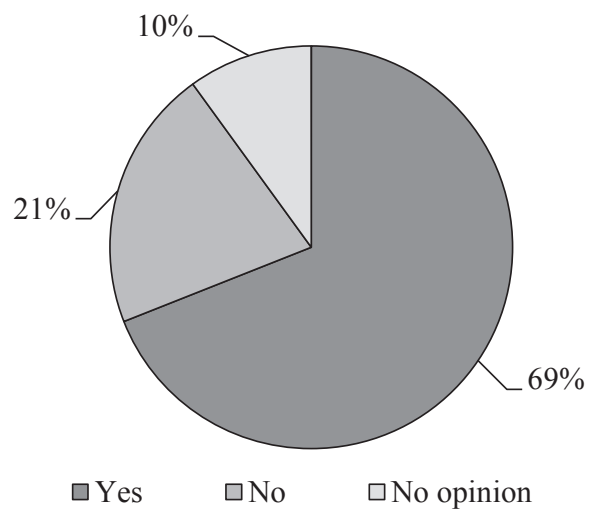

Fig. 2. The usefulness of CI in the respondents' decision-making process

Source: own study.

However, it is interesting and surprising that $66 \%$ of all investors used this information in financial analyses, but one-quarter of them were unable to give an unambiguous answer (see Figure 3). It is worth adding that most of them had also no opinion in the case of increasing the transparency or usefulness of CI (cf. Table 1). 


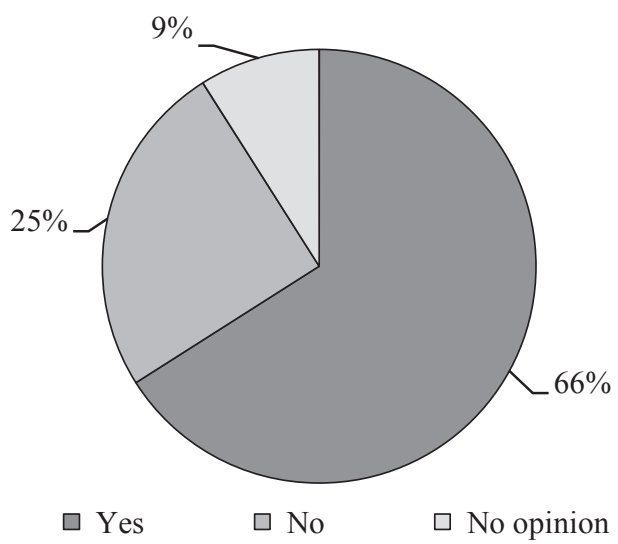

Fig. 3. The usefulness of $\mathrm{CI}$ in the financial analysis

Source: own study.

Non-professional investors were unanimous in their opinion that components of OCI are value-relevant, measured on a scale from 1 to 5 , where 5 means useful and 1 useless information. One can document that unrealised gains (losses) on remeasuring available-for-sale financial assets are the most value-relevant individual item, and the revaluation of property, plant, equipment and intangible assets was the most useless of all. On a scale from 1 to 5, their average level was 4.05 and 3.74, respectively. Other items received the average marks between 3.87 and 3.96 (see Table 2).

Table 2. The usefulness of OCI items

\begin{tabular}{|c|c|c|c|c|c|c|c|}
\hline \multirow{2}{*}{ OCI items } & \multicolumn{5}{|c|}{ Scale* } & \multirow{2}{*}{$\begin{array}{c}\text { No } \\
\text { opinion }\end{array}$} & \multirow{2}{*}{$\begin{array}{c}\text { Average } \\
\text { marks }\end{array}$} \\
\hline & 1 & 2 & 3 & 4 & 5 & & \\
\hline REV & 0 & 4 & 31 & 44 & 15 & 6 & 3.74 \\
\hline PENS & 0 & 5 & 19 & 47 & 23 & 6 & 3.94 \\
\hline FOREX & 0 & 5 & 20 & 42 & 26 & 7 & 3.96 \\
\hline AFS & 0 & 3 & 18 & 44 & 29 & 6 & 4.05 \\
\hline HEDGE & 0 & 5 & 24 & 40 & 22 & 9 & 3.87 \\
\hline
\end{tabular}

* On a scale from 1 to 5 , where 5 means useful and 1 useless information.

Marks: see Table 1.

Source: own study.

In many cases, comprehensive income was considered to be a better measure of economic efficiency and market value than net income. Six out of ten $(59 \%)$ individual investors disagree that NI is more susceptible to accounting manipulation (see Figure 4). It is worth mentioning that NI is an element of CI, so accounting 


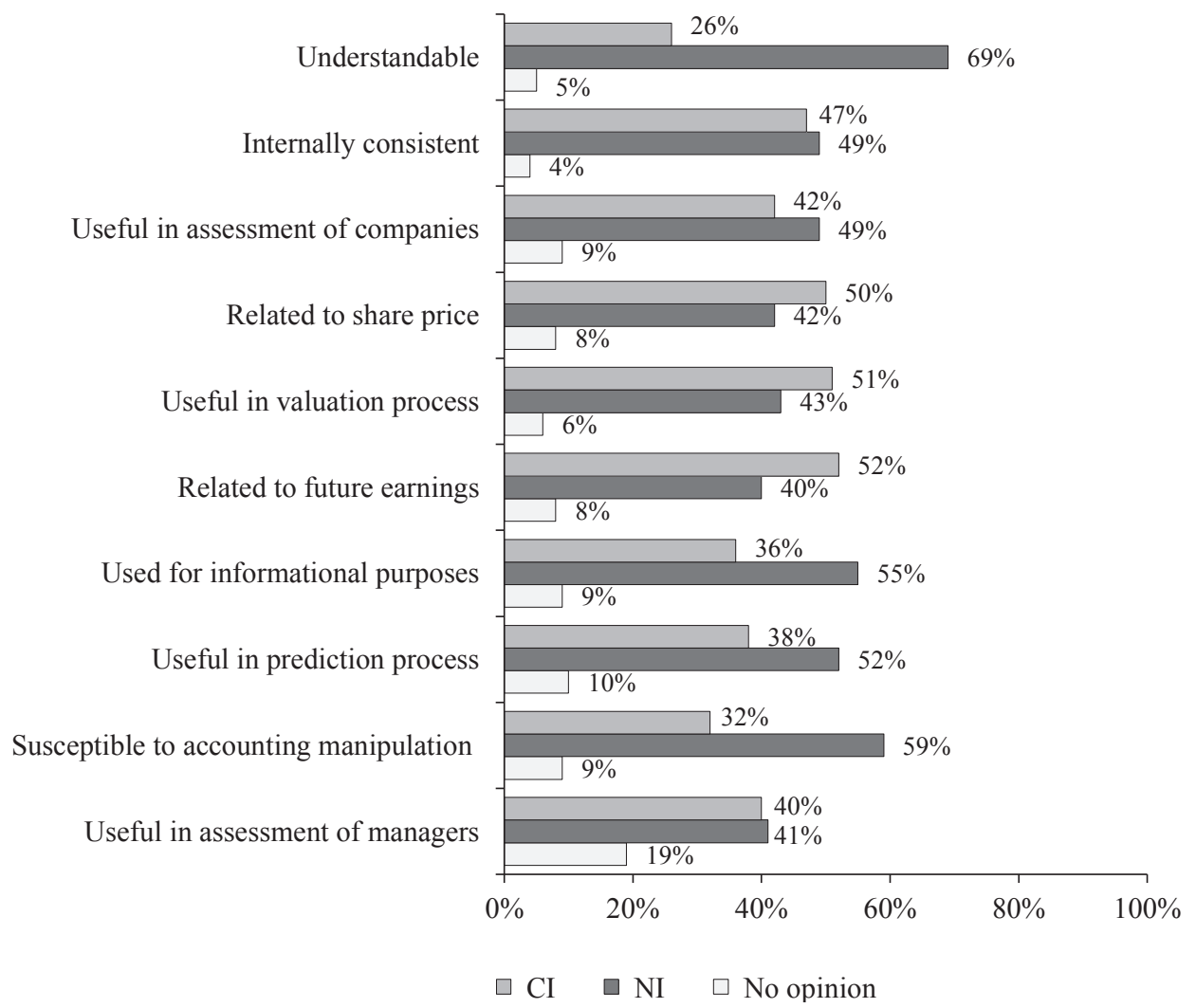

Fig. 4. Comparative analysis of CI and NI

Source: own study.

manipulation is also valid for CI. According to the respondents' opinions, CI is considered to be a better financial measure, and in particular that it is more useful for the purposes of company valuation, more related to the market price of shares, and has a higher predictive value, e.g. for future earnings. Approximately half of the respondents confirm these advantages of CI.

It is definitely worth emphasising that $\mathrm{CI}$ income was considered to be a better financial measure than net income especially for investors who had extensive investment knowledge and experience in IFRS as well as investment experience. In addition, this group of respondents assessed CI as important for making investment decisions and used this information in financial analyses (see Table 3).

Among the disadvantages of comprehensive income, which were presented by investors, there were statements that $\mathrm{NI}$ is definitely more understandable than CI, more useful in the assessment of companies and in the predicting process. This 
Table 3. The value relevance of CI

\begin{tabular}{|l|c|c|c|}
\hline \multirow{2}{*}{\multicolumn{1}{|c|}{ Investor characteristics }} & \multicolumn{3}{|c|}{ Advantages of CI compared to NI } \\
\cline { 2 - 4 } & $\begin{array}{c}\text { Higher usefulness } \\
\text { for the purposes } \\
\text { of company valuation }\end{array}$ & $\begin{array}{c}\text { Higher relation } \\
\text { to market prices } \\
\text { of shares }\end{array}$ & $\begin{array}{c}\text { Higher } \\
\text { predictive } \\
\text { value }\end{array}$ \\
\hline $\begin{array}{l}\text { Using CI in the financial decisions } \\
\text { process }\end{array}$ & $80.4 \%$ & $80.0 \%$ & $80.8 \%$ \\
\hline Using CI in the financial analysis & $78.4 \%$ & $82.0 \%$ & $78.8 \%$ \\
\hline $\begin{array}{l}\text { Good or very good investment } \\
\text { knowledge and experience }\end{array}$ & $70.6 \%$ & $82.0 \%$ & $78.8 \%$ \\
\hline $\begin{array}{l}\text { Good or very good knowledge and } \\
\text { experience in IFRS }\end{array}$ & $68.6 \%$ & $84.0 \%$ & $78.8 \%$ \\
\hline
\end{tabular}

Source: own study.

assumption raises many doubts and the financial reporting system, especially in the comprehensive income area, constitutes one of the most criticised elements of making investment decisions.

\section{Conclusions}

The conducted survey, on the basis of the sample of 100 individual investors allowed to state that financial reports should provide clear, understandable and comprehensive information, while the implementation of comprehensive income to the financial reporting system increased the transparency of information and allowed for more accurate financial analyses of joint stock companies. At this point it is worth emphasising that the respondents indicated both comprehensive income and its components as very important categories for the purpose of making investment decisions. These results are partially consistent with the findings from previous studies (Eaton et al., 2013), but they argue a certain advantage of comprehensive income over net income, which can increase the relevance of comprehensive income for users of financial statements as a very important measure.

On the basis of these results and findings, one can clearly confirm the hypothesis that $\mathrm{CI}$ is more useful for the purposes of company valuation, more related to the market price of shares, and has a higher predictive value, e.g. for future earnings. Similar findings were reported by Choi and Zang (2006), Kubota, Suda, and Takehara (2009), and Kanagaretnam, Mathieu, and Shehata (2009).

Apart from these empirical results, it must be stressed that one of the areas of information policy of companies that allows for the better assessment of the management quality by investors is the transparency and usefulness of the accounting measures, especially in the context of company performance. The presentation of the weaknesses and strengths of comprehensive income in companies can provide their 
owners and managers with some arguments and counterarguments for the creation and implementation of specific management strategies. These motives become more relevant in connection with the importance of financial statements in the context of the agency theory, and strictly speaking to the creation of conditions allowing for the coinciding of the information policy of managers and the expectations of other stakeholder groups.

\section{References}

Barton, J., Hansen, T. B., and Pownall, G. (2010). Which performance measures do investors around the world value the most and why? Accounting Review, 85(3), 753-789.

Bek-Gaik, B. (2013). Prezentacja innych dochodów całkowitych w sprawozdaniach finansowych wybranych spółek publicznych w Polsce w latach 2009-2011. Zeszyty Teoretyczne Rachunkowości, 70(126), 7-22.

Cahan, S. F., Courtenay, S. M., Gronnewoller, P. L., and Upton, D. R. (2000). Value relevance of mandated comprehensive income disclosures. Journal of Business Finance \& Accounting, 27(9/10), 1273-1301.

Choi, J.-H., and Zang, Y. (2006). Implication of comprehensive income disclosure for future earnings and analysts' forecasts. Seoul Journal of Business, 12(2), 77-109.

Eaton, T. V., Easterday, K. E., and Rhodes, M. R. (2013). The presentation of other comprehensive income: FASB's recent and proposed changes. The CPA Journal, 83(3), 32-35.

Epstein, B., Nach, R., and Bragg, S. (2010). GAAP 2010. Interpretation and application of generally accepted accounting principles. Hoboken, New Jersey: Wiley.

Gad, J. (2017). Forma sprawozdania z wyniku całościowego - perspektywa polskiego i niemieckiego rynku kapitałowego. Przeglad Organizacji, 5, 44-52.

Henry, E. (2011). Presentation of comprehensive income: another (small) step toward convergence. The Journal of Corporate Accounting \& Finance, 23(1), 85-90.

Hodder, L. D., Hopkins, P. E., and Wood, D. A. (2008). The effects of financial statement and informational complexity on cash flow forecasts. The Accounting Review, 83(4), 915-956.

Hoogervorst, H. (2012). The Imprecise Nature of Accounting: Questions on Measurement, Standard Setting and the IASB's Course for the Future. The CPA Journal, 82(8), s. 11-13.

Kanagaretnam, K., Mathieu, R., and Shehata, M. (2009). Usefulness of Comprehensive Income Reporting in Canada. Journal of Accounting and Public Policy, 28(4), 349-365.

Kang, S., and Zhao, Y. (2010). Information content and value relevance of depreciation: a cross-industry analysis. The Accounting Review, 85(1), 227-260.

Ketz, J. E. (1999). Comprehensive income: what do the numbers disclose? Journal of Corporate Accounting and Finance, 10(4), 79-96.

Kubota, K., Suda, K., and Takehara, H., Information content of other competensive income and net income: evidence for Japanese firms. Retrieved 23 April 2009 from: https://ssrn.com/abstract $=1393746$

Libby, R., Bloomfield, R., and Nelson, M. W. (2002). Experimental research in financial accounting. Accounting, Organizations and Society, 27(8), 775-810.

Maines, L. A., and McDaniel, L. S. (2000). Effects of comprehensive-income characteristics on non-professional investors' judgments: the role of financial-statement presentation format. The Accounting Review, 75(2), 179-207. 
Nelson, M. W., and Tayler W. B. (2007). Information pursuit in financial statement analysis: effects of choice, effort, and reconciliation. The Accounting Review, 82(3), 731-758.

Pronobis, P., and Zülch, H. (2011). The predictive power of comprehensive income and its individual components under IFRS. Problems and Perspectives in Management, 9(4), 72-88.

Ramond, O., Casta, J. F., and Lin S. (2007). Value relevance of comprehensive income: evidence from major European capital markets. Lisbon: European Accounting Association.

Sajnóg, A. (2017). The role of comprehensive income in predicting banks' future earnings based on the practice of banks listed on the Warsaw Stock Exchange. Equilibrium. Quarterly Journal of Economics and Economic Policy, 12(3), 485-500.

Szychta, A., and de la Rosa, D. (2012). Comprehensive income presentation under IAS 1: the reporting practices of the largest companies listed on the Warsaw Stock Exchange, Zeszyty Teoretyczne Rachunkowości, 68(124), 121-145. 